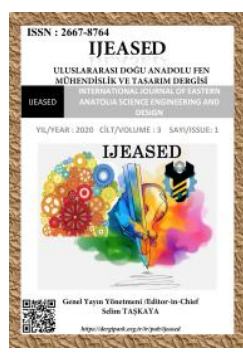

IJEASED INTERNATIONAL JOURNAL OF EASTERN ANATOLIA SCIENCE ENGINEERING AND DESIGN

Uluslararası Doğu Anadolu Fen Mühendislik ve Tasarım Dergisi ISSN: 2667-8764, 3(1), 350-364, 2021

https://dergipark.org.tr/tr/pub/ijeased

Araştırma Makalesi / Research Article

Doi: $\underline{\text { 10.47898/ijeased.879024 }}$

\title{
Şeker Pancarlarında Bitki Gelişimini Teşvik Eden Bakteri Biyoformülasyonlarının Verim ve Kalite Parametreleri Üzerine Etkileri
}

\author{
Fatma ŞIMŞEK $^{1 a^{*}}$, Recep KOTAN ${ }^{2}$, Fatih CEYHAN ${ }^{1 b}$, Çağlar SOYTÜRK ${ }^{1 c}$, Sabri BARAN ${ }^{1 d}$ \\ ${ }^{1}$ Kayseri SSeker Fabrikası A.Ş., Ar-Ge Merkezi, Kayseri, 38070, Türkiye. \\ ${ }^{2}$ Atatürk Üniversitesi, Ziraat Fakültesi, Bitki Koruma Bölümü, Fitopatoloji Anabilim Dalı, Erzurum, 25240, Türkiye.
}

\begin{tabular}{|c|c|c|}
\hline Yazar Kimliği / Author ID (ORCID Number) & Makale Süreci / Article I & Process \\
\hline $\begin{array}{l}\text { "Sorumlu Yazar / Corresponding author: } \\
\text { fatma.simsek@kayseriseker.com.tr } \\
\text { (iD) } \mathrm{https://orcid.org/0000-0002-3052-1195} \mathrm{,} \mathrm{F.} \mathrm{Şimşek} \\
\text { (iD) https://orcid.org/0000-0001-6493-8936, R. Kotan } \\
\text { (iD) } \mathrm{https://orcid.org/0000-0002-3927-8398} \\
\text {, F. Ceyhan } \\
\text { (iD) https://orcid.org/0000-0002-6963-9887 , Ç. Soytürk } \\
\text { (iD) https://orcid.org/0000-0002-7662-3015, S. Baran }\end{array}$ & $\begin{array}{l}\text { Geliş Tarihi / Received Date } \\
\text { Revizyon Tarihi / Revision Date } \\
\text { Kabul Tarihi / Accepted Date } \\
\text { Yayım Tarihi / Published Date }\end{array}$ & $\begin{array}{l}15.02 .2021 \\
20.04 .2021 \\
19.05 .2021 \\
15.07 .2021\end{array}$ \\
\hline
\end{tabular}

\section{Özet}

Çalışmada; Kayseri Şeker'e ait Gemerek (Sivas) ve Yahyalı (Kayseri) şeker pancarı ekiliş alanlarında, bakteri içerikli mikrobiyal gübre formülasyonlarının pancar verimi ve kalitesi üzerine etkisi araştırılmıştır. Çalışmada "Beta marka Zanzibar (NZ) çeşidi çılak tohum" tercih edilmiş ve 6 farklı bakteri izolatı (Pantoea agglomerans RK-79, Pantoea agglomerans RK-92, Bacillus megaterium TV-3D, Bacillus megaterium TV-6D, Paenibacillus polymyxa TV-12E ve Bacillus subtilis TV-17C) kullanılmıştır. Bu bakterilerden oluşturulan 3 farklı bakteri içerikli formülasyon ve kontrol (K) bakteri içermeyen sadece taşıyıcı sıvı ile kaplanmış tohumlar çiftçi arazilerinde şansa bağlı tesadüf blokları deneme desenine göre üç tekerrürlü olacak şekilde yürütülmüştür. Bölge çiftçilerinin kendi ekim alanlarında uygulamış oldukları toprak hazırlığı çalışmalarının aynısı deneme alanlarında yapılmışıı. Kimyasal gübre yarı yarıya azaltılmış ve Yahyalı bölgesindeki deneme arazisinde 4,55 kg/da N (Azot) ve 1,25 lt/da bakteri içerikli formülasyonlar uygulanırken kontrol sahasında $18,80 \mathrm{~kg} / \mathrm{da} \mathrm{N}$ kullanılmıştır. Gemerek bölgesindeki deneme arazisinde ise $14,10 \mathrm{~kg} / \mathrm{da} \mathrm{N}$ ve $0,75 \mathrm{lt} / \mathrm{da}$ bakteri içerikli formülasyonlar uygulanırken kontrol sahasında $26,10 \mathrm{~kg} / \mathrm{da} \mathrm{N}$ kullanılmıştır. Analiz sonuçlarına göre, Yahyalı 
Şimşek, F., ve ark., Uluslararası Doğu Anadolu Fen Mühendislik ve Tasarım Dergisi / International Journal of Eastern Anatolia Science Engineering and Design (IJEASED)

(2021) 3(1): 350-364

bölgesinde $\% 5.27$ verim $(\mathrm{kg} / \mathrm{da})$ artışı ve \%1.85 polar değeri artışı ile formülasyon 2 uygulaması iyi sonuç gösterirken, Gemerek bölgesinde \%16.48 verim (kg/da) artışı ve \%9.34 polar değeri artış1 ile formülasyon 3 uygulaması en iyi sonucu vermiştir. Bu sonuçlar dahilinde şeker pancarı tarımında verim ve çevre sağlığına yönelik ciddi kazanımların olabileceği öngörülmektedir.

Anahtar Kelimeler: Şeker Pancarı, Mikrobiyal Gübre, Verim Artışı, Kimyasal Gübre, Kayseri Şeker Fabrikası, PGPR.

\title{
Effects of Bacterial Bioformulations Promoting Plant Growth on Yield and Quality Parameters in Sugar Beet
}

\begin{abstract}
In this study; The effect of microbial fertilizer formulations containing bacteria on beet yield and quality were investigated in Gemerek (Sivas) and Yahyall (Kayseri), which are the cultivation areas of Kayseri Şeker. "Beta brand Zanzibar (NZ) variety naked seed". Six different bacterial isolates (Pantoea agglomerans RK-79, Pantoea agglomerans RK-92, Bacillus megaterium TV-3D, Bacillus megaterium TV-6D, Paenibacillus polymyxa TV-12E, and Bacillus subtilis TV-17C) were used in the study. 3 different bacteria-containing formulations created from these bacteria and the seeds coated with a carrier liquid that does not contain Control $(K)$ bacteria were carried out in three replications according to the random block trial design based on complete randomization. The same soil preparation application of the local farmers was applied in the experimental areas in their own cultivation areas. The chemical fertilizer was reduced by half and the formulations containing $4.55 \mathrm{~kg} / \mathrm{da} N$ (Nitrogen) and $1.25 \mathrm{lt} / \mathrm{da}$ bacteria were applied in the control area in Yahyall region. In the Gemerek region, $14.10 \mathrm{~kg} / \mathrm{da}$ N and $0.75 \mathrm{lt} / \mathrm{da}$ bacteria-containing formulations were applied, while 26.10 $\mathrm{kg} / \mathrm{da} \mathrm{N}$ was used in the control area. According to the results of the analysis, while the Formulation 2 application showed good results with $5.27 \%$ efficiency $(\mathrm{kg} / \mathrm{da}$ ) increase and $1.85 \%$ polar value increase in the Yahyal region, the increasi in Gemerek region was $16.48 \%$ yield $(\mathrm{kg} / \mathrm{da})$ increase and 9\%,, Formulation 3 application yielded the best results with an increase of 34 polar values. Within the scope of these results, it is predicted that there may be serious gains in yield and environmental health in sugar beet agriculture.
\end{abstract}

Keywords: Sugar Beet, Microbial Fertilizer, Yield Increase, Chemical Fertilizer, Kayseri Şeker Fabrikası, PGPR.

\section{Giriş}

Şeker pancarı (Beta vulgaris L.), Chenopodiaceae familyasına ait iki yıllık bir bitkidir. Ilıman iklim bölgelerinde ekonomik olarak önemli bir üründür ve dünya çapında şeker üretiminin yaklaşık \%25'ini oluşturur. Şeker endüstrisi, hayvancılık için yem takviyesinde yaygın kullanılan melas ve şeker pancarı posasını (küspe) büyük miktarlarda yan ürün olarak üretir. Küspe ve melas, şeker içeriklerinin yüksek olması nedeniyle kolayca mayalanabilmektedirler. Bu sayede küspe ve melas biyoethanol üretimi içinde büyük bir potansiyele sahiptir. Ayrıca alkol, maya ve ilaç endüstrileri için hammadde sunmaktadır (Taški-Ajduković ve ark., 2017; Çınar, 2018).

Şeker pancarı münavebe (ekim nöbeti) bitkisi olup, ekildiği tarlaya şeker pancarından sonra buğday, arpa, ayçiçeği, nohut, sarımsak gibi münavebe bitkilerinin ekilmesi beklenilir. Türkşeker 2019 Sektör Raporu T.C. Tarım ve Orman Bakanlığı verilerine göre 2011-2019 yılları arası Türkiye'de üretilen pancar miktarı (bin ton) ve elde edilen verim (ton/da) incelendiğinde; pancar 
miktarlarında yıllara göre bazı artışlar ve düşüşler gözlemlenmiş olsa da pancar verimi üzerinde olumsuz bir etki oluşturmamıştır. Bu durumun pancar kalitesi ile ilişkili olabileceği düşünülmektedir (URL-1). 2009 yılında yapılan bir çalışmada, şeker pancarı üreticileri için "Türkiye genelinde şeker pancarı üretimindeki düşüşlerinin sebeplerini” araştırmak için bir anket çalışması yapılmıştır. Üreticilerden; kota uygulaması, aşırı gübreleme, aşırı sulama ve hastalık/haşere artışının olumsuz etkileri yönünden kendi önceliklerine göre sıralamaları istenmiştir. Bu anketin sonucunda "kota uygulaması" birinci sırada, “aşırı gübreleme” ikinci sırada yer almıştır (Tuğcu, 2009). Şeker pancarı ve patates gibi toprak altı gövdesine sahip bitkilerin, topraktan besin alımı fazla olduğu için yetiştiriciliğinde çok yüksek miktarlarda kimyasal gübre kullanılması gerekmektedir. 2019 yılı verilerine göre Kayseri, Boğazlıyan ve Turhal Şeker fabrikaları bünyesinde şeker pancarı üretiminde ise 575.202 dekarlık alanda yılda ortalama 61.534 ton kimyasal gübre kullanılmaktadır (URL-2). Kimyasal gübrelerin tarım ürünlerinde verimlilik üzerine olumlu etki gösterdiği bilinmektedir ancak aşırı kullanımı toprağa zarar vermekte ve çevresel problemler ile beraber doğal kaynakların tükenmesine yol açmakta ve şeker pancarı tarımında şeker üretim maliyetlerini oldukça artırdığı bu proje sonuçlarıyla da desteklenmektedir.

Kimyasal ilaç ve gübre kullanımı çevreye ve insan sağlığına verdiği zararlar ile doğal kaynakların kirlenmesine, toprak yapılarının bozulmasına da sebep olmaktadır. Szekeres ve ark. (2016) sürdürülebilir tarım uygulamalarında önemli noktalardan birisinin biyolojik mücadele olduğunu belirtmişlerdir. Gökçe ve Kotan (2016) bakteriyel biyolojik ajanlarının bitki de dayanıklılığı uyararak hastalıkların gözlemlenmesinin de azaldığını ve bitkilerin tüm dokularında olumlu etki gösterdiğini ifade etmişlerdir.

Son yıllarda kullanımları yaygınlaşan, doğrudan ya da dolaylı olarak bitki gelişimini olumlu etkileyen, topraktaki patojenlere karşı koruma sağlayan, çevre sağlığını olumlu etkileyen bakteriler "Bitki Gelişiminini Teşvik Edici Bakteriler (PGPR)" olarak adlandırılmakta ve biyolojik gübre olarak kullanım alanları her geçen gün artmaktadır. Yapılan araştırmalara göre bakteriler, bitkilerin büyüme mekanizmalarını etkilemekte ve bazı fizyolojik değişimlere sebep olmaktadır (Çınar, 2018; Çakmakçı, 2005). Karagöz ve Dursun (2019) yaptıkları bir çalışmada, PGPR formülasyonları, kimyasal gübre ve kombinasyonlarının Atatürk Çiçeği (Euphorbia pulcherrima) bitkisinde bazı gelişim parametrelerine etkilerini araştırmışlar ve bakteriyel formülasyonların Atatürk Çiçeği bitkisine faydalı olduğunu, kimyasal gübre kullanımının azaltılabileceğini bildirmişlerdir. Bazı 
Şimşek, F., ve ark., Uluslararası Doğu Anadolu Fen Mühendislik ve Tasarım Dergisi / International Journal of Eastern Anatolia Science Engineering and Design (IJEASED)

(2021) 3(1): 350-364

araştırıcıların şeker pancarında bakteriyel formülasyon kullanımları üzerine yapılmış çalışmalarında, ürünün verimi üzerine \%16.9'a kadar bir artış olduğunu bildirilmişlerdir (Chen ve ark., 1996).

Şeker pancarı üretiminde; gübre maliyetinin yeri ve önemi, kimyasal gübrelerin çevreye ve toprağa verdikleri zararlar, hastalık ve patojenlerin bitkiye verdiği zararların azaltılması gibi konular ele alınarak bu çalışma planlanmıştır. Çalışmada biri kontrol olmak üzere ve üç farklı bakteri içerikli mikrobiyal gübre formülasyonlarının, kimyasal gübre ile birlikte etkileşimlerinin çiftçi arazi sahalarında değerlendirilmesi amaçlanmıştır.

\section{Materyal ve Yöntem}

Çalışmada, ülkemizdeki çeşitli kültür ve yabani bitkilerin toprak üstü aksamı veya kök rizosferinden daha önceki çalışmalarda izole edilen, moleküler sistemlerden MIS sistemi kullanılarak tanılanan, azot fiksasyonu yapabildikleri ve fosfatı çözebildikleri tespit edilen toplam 6 bakteri izolatı kullanılmıştır. Kullanılan bakterilerin listesi Tablo 1'de verilmiştir. Bu izolatlar Atatürk Üniversitesi, Ziraat Fakültesi, Bitki Koruma Bölümünde Mikroorganizma Kültür Koleksiyonunda muhafaza edilmektedir

Tablo 1. Çalışmada kullanılan bakteri izolatları

\begin{tabular}{clccc}
\hline İzolat no & MIS Tanı Sonuçları & Azot & Fosfat & Kaynak \\
\hline RK-79 & Pantoea agglomerans & + & + & Kotan, 2002; Gökçe ve ark.,2014 \\
RK-92 & Pantoea agglomerans & + & $\mathrm{K}+$ & Kotan, 2002; Gökçe ve ark.,2014 \\
TV-3D & Bacillus megaterium & $\mathrm{K}+$ & + & Erman ve ark.., 2010; Ekinci ve ark.., 2014 \\
TV-6D & Bacillus megaterium & + & + & Erman ve ark., 2010; Ekinci ve ark., 2014 \\
TV-12E & Paenibacillus polymyxa & $\mathrm{K}+$ & + & Erman ve ark., 2010; Ekinci ve ark., 2014 \\
TV-17C & Bacillus subtilis & $\mathrm{K}+$ & $\mathrm{Z}+$ & Erman ve ark., 2010; Ekinci ve ark., 2014 \\
\hline
\end{tabular}

İklimsel ve ekolojik özellikleri birbirinden farklı (Yahyalı bölgesinde karasal iklim hakim olmakla beraber Akdeniz ikliminin etkileri de görülürken, Gemerek bölgesinde karasal iklim hakim) 2 lokasyonda çiftçi tarlaları kullanılarak (Kayseri ili Yahyalı ilçesi Kopçu köyü ve Sivas ili Gemerek ilçesi Karagöl köyü) uygulama yapılmıştır. Tohumlar üç farklı bakteri formülasyonu ile kodlanmıştır. Kontrol olarak sıvı taşıyıcı kullanılmıştır. Formülasyonlarda kullanılan bakteri izolatları Tablo 2'de verilmiştir.

Tablo 2. Çalışmada kullanılan formülasyonlardaki bakteri içerikleri

\begin{tabular}{lccccc}
\hline Formülasyonlar & \multicolumn{5}{c}{ Formülasyon İçeriklerindeki Bakteri İzolatları } \\
\hline Formülasyon 1 & TV-3D & TV-6D & TV-12E & RK-79 & RK-92 \\
Formülasyon 2 & TV-6D & RK-92 & TV-17C & - & - \\
Formülasyon 3 & TV-3D & TV-6D & RK-92 & - & - \\
\hline
\end{tabular}

Tarlaların ekim planı, bölünmüş parseller deneme deseninde 3 tekerrürlü olarak tasarlanmıştır. 
Ekimler, bölgelerin iklim şartlarına göre uygun zamanda (6-9 Nisan 2018) pancar ekim mibzeri ile sıra üzeri $10 \mathrm{~cm}$ (20 cm teklenmiştir), sıra arası $45 \mathrm{~cm}$ olarak yapılmıştır. Çalışmada kök verimi ve şeker verimi yüksek, bazı pancar hastalıklarına toleranslı, makineli hasada uygun, silolama kalitesi yüksek özelliklerine sahip (Beta marka Zanzibar Çeşidi Pancar Tohumu (NZ)) çıplak tohum kullanılmıştır.

Tohumlar ekim yapılmadan önce distile su ile yıkandıktan sonra yukarıda belirtilen bakteri ırklarını içeren formülasyonlar ile başka işleme tabi tutulmadan kaplanarak kurumaya bırakılmıştır. Kontrol ve deneme arazilerindeki gübreleme miktarları, bölgeler arasındaki iklim ve toprak farklılıkları nedeniyle değişiklik göstermiştir. Özellikle bölgelerde yaygın olarak şeker pancarı bitkisi için uygulanan dozlar dikkate alınmıştır. Uzun yıllar gübre kullanımındaki farklılıklara bağlı olarak topraktaki besin element düzeylerinde değişkenlikler meydana gelmiştir. Şeker pancarı bitkisinin optimum gelişim gösterebileceği besin element düzeyi baz alınarak, bölgesel $\mathrm{N}$ gübresi ve bakteri uygulama dozları belirlenmiş ve çiftçilerin önceki yıllarda uygulamış oldukları N (azot) miktarlarını \%50 azaltarak uygulamaları istenilmiş ve buna göre miktarlar; Yahyalı bölgesindeki deneme arazisinde 4,55 kg/da N ve 1,25 lt/da bakteri içerikli formülasyonu kontrol sahasında 18,80 kg/da N gübresi, Gemerek bölgesindeki deneme arazisinde ise $14,10 \mathrm{~kg} / \mathrm{da} \mathrm{N}$ ve 0,75 lt/da bakteri içerikli formülasyonu uygulanırken kontrol sahasında 26,10 kg/da $\mathrm{N}$ gübresi kullanılmıştır.

Uygulamalar sonrası şeker pancarının gelişim süreci devam ederken, tekleme, çapa ve bakım işlemleri yapılmıştır. Zorunlu durumlarda uygulanacak herbisitler ve insektisitler bakteriye sorun oluşturmayacağı dönemlerde ve uygun kimyasallar seçilerek optimum doz belirlenip uygulanması planlanmış fakat herhangi bir kimyasal uygulamasına ihtiyaç duyulmamıştır. Sulama yöntemi yağmurlama sulama ile homojen bir dağılım sağlanacak biçimde yapılmıştır.

Hasat döneminde numuneler alındıktan sonra tek sıralı söküm makinesiyle şeker pancarları hasat edilmiştir. Pancarın bütün vejetatif gelişim döneminde ilk çimlenmeden başlayıp bütün gelişim evreleri hastalık ve zararlılara karşı direnci de dahil olmak üzere gözlemlenmiştir. Her parselden $10 \mathrm{~m}^{2}$ ’lik alanlardan numune sökülmüş, sayımı yapılarak tartılmış ve verimlerin ortalamaları alınarak hesaplanmıştır. Her parselden 15 pancar rastgele seçilip Kayseri Şeker Fabrikası Pancar Analiz Laboratuvarına getirilmiş ve Betalyser sisteminde Sakkaroz $\left({ }^{\circ} \mathrm{Z}\right)$, Sodyum(Na), Potasyum $(\mathrm{K})$ ve Zararlı Azot (Alfa-Amino N) değerlerine bakılmıştır. Ayrıca Erciyes Üniversitesi, Ziraat Fakültesi, Toprak Bilimi ve Bitki Besleme Bölümü’nde makro-mikro besin element analizleri için şeker 
Şimşek, F., ve ark., Uluslararası Doğu Anadolu Fen Mühendislik ve Tasarım Dergisi / International Journal of Eastern Anatolia Science Engineering and Design (IJEASED)

(2021) 3(1): 350-364

pancarlarının gövde kısmından alınan numuneler, etüvde $70^{\circ} \mathrm{C}$ sıcaklıkta 1 gece bekletildikten sonra öğütülüp toz haline getirilmiş “kuru pancar” numunelerinin analizleri yapılmıştır.

Betalyser, şeker pancarındaki şeker içeriği ( $\left.{ }^{\circ} \mathrm{Z} / \mathrm{Digestion}\right)$ ve melas oluşturan bileşenler (Na, K, Alfa-Amino N) bakımından resmi ICUMSA (International Commission for Uniform Methods of Sugar Analysis) metotlarına göre kalite kontrolü ve analizleri gerçekleştirmeyi hedefleyen bilgisayar kontrollü bir laboratuvar sistemidir (URL-3: https://www.foodonline.com/doc/betalyser-0001). Araştırma süresince analizler hasat döneminde alınan örneklere üç tekrarlı yapılmıştır.

Resmi Gazete 24799 sayılı 28.06.2002 tarihinde yayınlanan "Hammadde ve Şeker Fiyatları Yönetmeliği’ne” göre, fire; üreticilerden teslim alınan pancardaki yaprak, toprak, çamur, kuyruk ve düzgün kesilmeyen baş kısmı vb. yabancı maddelerin teslim alınan pancara göre yüzdesini ifade etmektedir. Bu araştırma kapsamında ise fire \%7 olarak kabul edilmiştir (URL-4).

Pancar örneklerinde $\mathrm{P}, \mathrm{Ca}, \mathrm{Mg}, \mathrm{S}, \mathrm{Fe}, \mathrm{Cu}, \mathrm{Mn}, \mathrm{Zn}, \mathrm{B}, \mathrm{Cd}, \mathrm{Cr}$, Ni ve Pb element içerikleri nitrik asit-perklorik asit (4:1) ile yakmaya tabi tutulduktan (Mertens, 2005a) sonra ICP OES spektofotometresinde (Inductively Coupled Plasma spectrophotometer) okunmak suretiyle belirlenmiştir (Mertens, 2005b).

Betalyser ve ICP cihazlarından elde edilen laboratuvar sonuçları, \%95'lik güvenilirlik düzeyinde $(\mathrm{p}<0,05)$, gruplara (Yahyalı ve Gemerek bölgesi, deneme alanı ve kontrol alanı) göre istatistiksel olarak anlamlı olup olmadığının anlaşılması için SPSS programı One-Way ANOVA, Post-Hoc LSD Testi kullanılmıştır.

\section{Bulgular ve Tartışma}

\section{1. Şeker Pancarı Bitkisinde Bakteri Uygulamasının Polar, Verim ve Kalite Parametrelerine} Etkisi

\subsubsection{Gemerek Bölgesi}

Bakteri uygulamalarının; Gemerek bölgesinde şeker pancarındaki digestion ve verim (\%) oranları olmak üzere bazı kalite ve verim parametreleri ile dekardaki ağırlığı üzerine etkilerini gösteren sonuçlar Tablo 3'de verilmiştir. 
Tablo 3. Gemerek bölgesinde bakteri uygulamaları ile elde edilmiş betalyser cihazı analiz sonuçları $(\mathrm{p}<0.05)$

\begin{tabular}{ccccccc}
\hline Uygulamalar & Digestion & $\mathbf{N a}$ & $\mathbf{K}$ & $\mathbf{N}$ & Verim $(\%)$ & Verim $(\mathbf{k g} / \mathbf{d a})$ \\
\hline $\begin{array}{c}\text { Formülasyon } \\
1\end{array}$ & $17.52^{\mathrm{a}}$ & $1.14^{\mathrm{a}}$ & $4.47^{\mathrm{a}}$ & $1.51^{\mathrm{a}}$ & $15.88^{\mathrm{a}}$ & $12836.67^{\mathrm{a}}$ \\
$\begin{array}{c}\text { Formülasyon } \\
2\end{array}$ & $16.92^{\mathrm{a} . \mathrm{b}}$ & $1.14^{\mathrm{a}}$ & $4.48^{\mathrm{a}}$ & $1.70^{\mathrm{a}}$ & $15.24^{\mathrm{a}}$ & $13015.00^{\mathrm{a}}$ \\
$\begin{array}{c}\text { Formülasyon } \\
3\end{array}$ & $17.76^{\mathrm{a}}$ & $0.82^{\mathrm{a}}$ & $4.36^{\mathrm{a}}$ & $1.26^{\mathrm{a}}$ & $16.23^{\mathrm{a}}$ & $12365.00^{\mathrm{a}}$ \\
Kontrol & $16.24^{\mathrm{b}}$ & $1.79^{\mathrm{b}}$ & $5.59^{\mathrm{a}}$ & $3.41^{\mathrm{b}}$ & $13.94^{\mathrm{b}}$ & $12700.00^{\mathrm{a}}$ \\
\hline
\end{tabular}

Digestion oranı bakımından şeker pancarı incelendiğinde, bakteri uygulamalarına göre digestion oranındaki değişim, istatistiksel olarak önemli bulunmuştur $(p<0.05)$. En yüksek digestion oranı formülasyon 3 uygulamasından elde edilirken (17.76), en düşük değer ise kontrolden elde edilmiştir (16.24). Formülasyon 2 ve formülasyon 1 uygulamalarından elde edilen değerler kontrole göre yüksek, formülasyon 3 uygulamasına göre daha düşük ölçülmüştür. Formülasyon 3 uygulamasında kontrole göre digestion oranında \%9.35 oranında artış meydana gelmiştir. Sodyum (Na) bakımından şeker pancarları incelendiğinde, bakteri uygulamalarına göre Na oranındaki değişim istatistiksel olarak anlamlı bulunmuştur $(\mathrm{p}<0.05)$. En düşük Na oranı formülasyon 3 uygulamasından elde edilirken (0.82), en yüksek değer ise kontrolden elde edilmiştir (1.79). Formülasyon 2 ve formülasyon 1 uygulamalarından elde edilen değerler kontrole göre düşük olurken, formülasyon 3 uygulamasına göre yüksek ölçülmüştür. Formülasyon 3 uygulamasında, kontrole göre Na oranında \%54.18 oranında azalış meydana gelmiştir. K bakımından şeker pancarı incelendiğinde, bakteri uygulamalarına göre K oranındaki değişim istatistiksel olarak anlamlı bulunmamıştır $(\mathrm{p}<0.05)$. En yüksek K oranı kontrolden elde edilirken (5.59), en düşük değer ise formülasyon 3 uygulamasından (4.36) elde edilmiştir. Formülasyon 2 ve formülasyon 1 uygulamalarından elde edilen değerler kontrole göre düşük olurken, formülasyon 3 uygulamasına göre yüksek ölçülmüştür. Formülasyon 3 uygulaması ile kontrole göre K oranında \%22.00 oranında azalış meydana gelmiştir. N bakımından şeker pancarı incelendiğinde, bakteri uygulamalarına göre $\mathrm{N}$ oranındaki değişim istatistiksel olarak anlamlı bulunmuştur $(\mathrm{p}<0.05)$. En düşük $\mathrm{N}$ oranı formülasyon 3 uygulamasından elde edilirken (1.26), en yüksek değer (3.41) ise kontrolden elde edilmiştir. Formülasyon 2 ve formülasyon 1 uygulamalarından elde edilen değerler kontrole göre düşük olurken, formülasyon 3 uygulamasına göre yüksek ölçülmüştür. Formülasyon 3 uygulaması ile kontrole göre N oranında \%63.04 oranında azalış meydana gelmiştir. Verim\% (Arıtılmışşeker oranı) bakımından şeker pancarı incelendiğinde, bakteri uygulamalarına göre verim\% oranındaki değişim istatistiksel olarak anlamlı bulunmuştur 
Şimşek, F., ve ark., Uluslararası Doğu Anadolu Fen Mühendislik ve Tasarım Dergisi / International Journal of Eastern Anatolia Science Engineering and Design (IJEASED)

(2021) 3(1): 350-364

$(p<0.05)$. En yüksek verim\% oranı formülasyon 3 uygulamasından elde edilirken (16.23), en düşük değer (13.94) ise kontrolden elde edilmiştir. Formülasyon 2 ve formülasyon 1 uygulamalarından elde edilen değerler kontrole göre yüksek olurken, formülasyon 3 uygulamasına göre düşük ölçülmüştür. Formülasyon 3 uygulaması ile kontrole göre verim\% oranında \%16.42 oranında artış meydana gelmiştir. Dekardaki ağırlık oranı (verim kg/da) bakımından şeker pancarı incelendiğinde, bakteri uygulamalarına göre verim $\mathrm{kg} / \mathrm{da}$ oranındaki değişim istatistiksel olarak anlamlı bulunmamıştır $(\mathrm{p}<0.05)$. En yüksek verim $\mathrm{kg} / \mathrm{da}$ oranı formülasyon 2 uygulamasından elde edilirken $(13.015,00)$, en düşük değer ise formülasyon 3 uygulamasından elde edilmiştir $(12.365,00)$.

\subsubsection{Yahyalı bölgesi}

Bakteri uygulamalarının; Yahyalı bölgesinde șeker pancarındaki digestion ve verim (\%) oranları olmak üzere bazı kalite ve verim parametreleri ile dekardaki ağırlığı üzerine etkilerini gösteren sonuçlar Tablo 4'de verilmiştir.

Tablo 4. Yahyalı bölgesinde bakteri uygulamaları ile elde edilmiş betalyser cihazı analiz sonuçları $(\mathrm{p}<0.05)$

\begin{tabular}{ccccccc}
\hline Uygulamalar & Digestion & Na & $\mathbf{K}$ & $\mathbf{N}$ & Verim $(\%)$ & Verim $(\mathbf{k g} / \mathbf{d a})$ \\
\hline $\begin{array}{c}\text { Formülasyon } \\
1\end{array}$ & $17.06^{\mathrm{a}}$ & $0.60^{\mathrm{a}}$ & $4.78^{\mathrm{a}}$ & $0.86^{\mathrm{a}}$ & $15.61^{\mathrm{a}}$ & $9390.00^{\mathrm{a}}$ \\
$\begin{array}{c}\text { Formülasyon } \\
2\end{array}$ & $17.09^{\mathrm{a}}$ & $0.55^{\mathrm{a}}$ & $4.62^{\mathrm{a}}$ & $0.93^{\mathrm{a}}$ & $15.65^{\mathrm{a}}$ & $8930.00^{\mathrm{a}}$ \\
$\begin{array}{c}\text { Formülasyon } \\
3\end{array}$ & $16.87^{\mathrm{a}}$ & $0.63^{\mathrm{a}}$ & $4.85^{\mathrm{a}}$ & $0.97^{\mathrm{a}}$ & $15.38^{\mathrm{a}}$ & $8631.67^{\mathrm{a}}$ \\
Kontrol & $16.48^{\mathrm{a}}$ & $1.04^{\mathrm{b}}$ & $4.78^{\mathrm{b}}$ & $1.34^{\mathrm{b}}$ & $14.87^{\mathrm{b}}$ & $9295.00^{\mathrm{a}}$ \\
\hline
\end{tabular}

Digestion oranı bakımından şeker pancarı incelendiğinde, bakteri uygulamalarına göre digestion oranındaki değişim istatistiksel olarak önemli bulunmamıştır $(p<0.05)$. En yüksek digestion oranı formülasyon 2 uygulamasından elde edilirken (17.09), en düşük değer ise kontrolden elde edilmiştir (16.48). Formülasyon 3 ve formülasyon 1 uygulamalarından elde edilen değerler kontrole göre yüksek iken, formülasyon 2 uygulamasına göre düşük ölçülmüştür. İstatistiksel olarak anlamlı olmamasına rağmen formülasyon 2 uygulaması ile kontrole göre digestion oranında $\% 3.70$ oranında artış meydana gelmiştir. Na bakımından şeker pancarı incelendiğinde, bakteri uygulamalarına göre $\mathrm{Na}$ oranındaki değişim istatistiksel olarak anlamlı bulunmuştur $(\mathrm{p}<0.05)$. En düşük $\mathrm{Na}$ oranı formülasyon 2 uygulamasından elde edilirken (0.55), en yüksek değer ise kontrolden elde edilmiştir (1.04). Formülasyon 3 ve formülasyon 1 uygulamalarından elde edilen değerler kontrole göre düşük 
olurken, formülasyon 2 uygulamasına göre yüksek ölçülmüştür. Formülasyon 2 uygulaması ile kontrole göre $\mathrm{Na}$ oranında \% 47.11 oranında azalış meydana gelmiştir. K bakımından şeker pancarı incelendiğinde, bakteri uygulamalarına göre $\mathrm{K}$ oranındaki değişim istatistiksel olarak anlamlı bulunmuştur $(\mathrm{p}<0.05)$. En yükssek K oranı formülasyon 3 uygulamasından elde edilirken $(4,85)$, en düşük değer ise formülasyon 1 uygulaması ve kontrolden elde edilmiştir (4,78). Formülasyon 2 uygulamasından elde edilen değer ise 4,62 ile en düşük değer olarak ölçülmüştür. Formülasyon 3 uygulaması ile kontrole göre K oranında \%1.46 oranında azalış meydana gelmiştir. N bakımından şeker pancarı incelendiğinde, bakteri uygulamalarına göre $\mathrm{N}$ oranındaki değişim istatistiksel olarak anlamlı bulunmuştur $(\mathrm{p}<0.05)$. En düşük $\mathrm{N}$ oranı formülasyon 1 uygulamasından elde edilirken $(0,86)$, en yüksek değer ise kontrolden elde edilmiştir $(1,34)$. Formülasyon 2 ve formülasyon 3 uygulamalarından elde edilen değerler kontrole göre düşük olurken, formülasyon 3 uygulamasına göre yüksek ölçülmüştür. Formülasyon 1 uygulaması ile kontrole göre N oranında \%55.81 oranında azalış meydana gelmiştir. Verim\% (Arıtılmış şeker oranı) bakımından şeker pancarı incelendiğinde, bakteri uygulamalarına göre verim\% oranındaki değişim istatistiksel olarak anlamlı bulunmuştur (p<0.05). En yüksek verim\% oranı formülasyon 2 uygulamasından elde edilirken $(15,65)$, en düşük değer ise kontrolden elde edilmiştir (14,87). Formülasyon 1 ve formülasyon 3 uygulamalarından elde edilen değerler kontrole göre yüksek olurken, formülasyon 2 uygulamasına göre düşük ölçülmüştür. Formülasyon 3 uygulaması ile kontrole göre verim\% oranında \%5.24 oranında artış meydana gelmiştir. Dekardaki ağırlık oranı (Verim kg/da) bakımından şeker pancarı incelendiğinde, bakteri uygulamalarına göre verim $\mathrm{kg} / \mathrm{da}$ oranındaki değişim istatistiksel olarak anlamlı bulunmamıştır $(\mathrm{p}<0.05)$. En yüksek verim $\mathrm{kg} / \mathrm{da}$ oranı formülasyon 1 uygulamasından elde edilirken $(9.390,00)$, en düşük değer ise formülasyon 3 uygulamasından elde edilmiştir $(8.631,67)$.

Çakmakçı ve ark. (2012) yaptıkları bir çalışmada, PGPR aşılaması yapılan topraklardan şeker pancarı bitkisinde daha yüksek verim bekleneceği sonucunu çıkarmışlardır. Çakmakçı ve ark. (2006) 'nın bir diğer çalışmasında ise, aşırı gübre kullanımından kaynaklanan çevre kirliliği ve kimyasal gübre üretimine kıyasla çalışmada test edilen bakterilerin daha sürdürülebilir ve çevre dostu tarımsal üretim için kullanılabileceği sonucuna varılmıştır. Meena ve Rai (2017) çalışmasında Triticum aestivum üzerine PGPR'ların etkilerini tespit etmişler ve denemesi yapılan 3 bakteri izolatı grubunda kontrole göre daha iyi performans gösterdiğini bildirmişlerdir. Artyszak ve Gozdowski (2020) yaptıkları çalışmada, PGPR kullanarak şeker pancarının şeker verimini düşürmeden \%30 daha az kimyasal gübre kullanılabileceğini ifade etmişlerdir. Yağmur ve Güneş (2021) çalışmasında domates 
Şimşek, F., ve ark., Uluslararası Doğu Anadolu Fen Mühendislik ve Tasarım Dergisi / International Journal of Eastern Anatolia Science Engineering and Design (IJEASED)

(2021) 3(1): 350-364

(Solanum lycopersicum) bitkisi üzerine PGPR'ların etkilerini araştırmışlar ve deneme grubunun kontrol grubuna göre yaklaşık \%20 verim artışına sebep olduğunu bildirmişlerdir. Seema ve ark. (2018) çalışmalarında çilek (Fragaria ananassa) bitkisinde PGPR'ların kök + yaprak uygulamasının büyüme, verim ve meyve kalitesi açısından iyi sonuçları verdiğini ifade etmişlerdir. Farzana ve ark. (2021) çalışmalarında Ipomoea batatas L. üzerine PGPR ve farklı N gübresi dozajlarının (0, 33 ve $100 \mathrm{~kg} \mathrm{~N} \mathrm{ha}^{-1}$ ) verime olan etkisi araştırılmıştır. Çalışma sonucunda en iyi verimi PGPR, $33 \mathrm{~kg} \mathrm{~N} \mathrm{ha-}$ ${ }^{1}$ uygulamasından elde ettiklerini ifade etmişlerdir. Khan ve Bano (2019) çalışmasında su stresi çeken tarla bitkilerine PGPR uygulaması yapıldıktan sonra büyüme üzerine etkileri ve verimlerini incelemişler çalışma sonucunda PGPR'ların bitkilerde kök büyümesini sağlayarak kuraklık toleranslarını iyileştirdiklerini ifade etmişler ve aynı zamanda besin alımını da iyileştirdiğini özellikle de tahıllarda etkili olduğunu bildirmişlerdir.

Serbest yaşayan bakteriler, besin kaynağı olarak toprak organik maddesine bağlı olduğundan, toprağa organik madde eklenmesi, PGPR'nin azot fiksasyonunu ve bitki büyümesini teşvik edici aktivitesini artırabileceği yukarıdaki literatür çalışmalarında gözlendiği gibi bizim çalışmamızda literatür ile uyumlu olmuştur. Çalışmadaki iki bölgede de PGPR'ların faydalı olduğu görülmüştür. İki bölgede farklı bakteri gruplarının daha iyi sonuç gösteriyor olması, bölgesel iklim farklılıkları, toprak yapısı ve çiftçinin kullandığı kimyasal gübre miktarına bağlı olabileceği düşünülmüştür. Bunların yanı sıra her iki bölgede de şeker pancarı için en önemli besin elementleri arasında yer alan $\mathrm{Na}, \mathrm{K}$ ve $\mathrm{N}$ elementlerinin etkileri de istatistiksel olarak anlamlı bulunmuş ve literatür ile uyumlu olduğu belirlenmiştir.

\section{2. Şeker Pancarı Bitkisinde Bakteri Uygulamasının Makro ve Mikro Elementlere Etkisi}

\subsubsection{Gemerek bölgesi}

Tablo 5. Gemerek bölgesinde bakteri uygulamaları ile elde edilmiş hasat sonrası kuru pancar numuneleri ICP analiz sonuçları $(\mathrm{p}<0.05)$

\begin{tabular}{|c|c|c|c|c|c|c|c|c|c|c|c|c|c|}
\hline Uygulamalar & B & $\mathbf{C a}$ & Cd & $\mathrm{Cr}$ & $\mathbf{C u}$ & $\mathbf{F e}$ & Mg & Mn & $\mathbf{N i}$ & $\mathbf{P}$ & $\mathbf{P b}$ & $\mathbf{S}$ & $\mathbf{Z n}$ \\
\hline $\begin{array}{c}\text { Formülasyon } \\
1\end{array}$ & $8.71^{\mathrm{a}}$ & $1602.92^{\mathrm{a}}$ & $0.21^{\mathrm{a}}$ & $3.08^{\mathrm{a}}$ & $3.88^{\mathrm{a}}$ & $593.08^{\mathrm{a}}$ & $995.79^{a}$ & $22.88^{\mathrm{a}}$ & $3.42^{\mathrm{a}}$ & $592.00^{\mathrm{a}}$ & $8.88^{\mathrm{a}}$ & $75.21^{\mathrm{a}}$ & $34.25^{\mathrm{a}}$ \\
\hline $\begin{array}{c}\text { Formülasyon } \\
2\end{array}$ & $7.88^{\mathrm{a}}$ & 1 & $0.00^{\mathrm{a}}$ & $3.83^{\mathrm{a}}$ & 3.58 & $6^{\mathrm{a}}$ & $0^{\mathrm{a}}$ & $3^{\mathrm{a}}$ & $3.04^{\mathrm{a}}$ & $63^{\mathrm{a}}$ & a.b & $5^{\mathrm{a}}$ & $6.08^{\mathrm{a}}$ \\
\hline $\begin{array}{c}\text { Formülasyon } \\
\mathbf{3}\end{array}$ & $8.75^{\mathrm{a}}$ & $1732.96^{\mathrm{a}}$ & $0.00^{\mathrm{a}}$ & $2.58^{\mathrm{a}}$ & $3.67^{\mathrm{a}}$ & $558.92^{\mathrm{a}}$ & $1015.96^{\mathrm{a}}$ & $25.83^{\mathrm{a}}$ & $3.50^{\mathrm{a}}$ & $624.33^{\mathrm{a}}$ & $10.67^{\mathrm{a} . \mathrm{b}}$ & $540.04^{\mathrm{a}}$ & $24.21^{\mathrm{a}}$ \\
\hline Kontrol & $6.75^{\mathrm{a}}$ & $973.75^{\mathrm{a}}$ & $0.13^{\mathrm{a}}$ & $0.88^{\mathrm{b}}$ & $3.50^{\mathrm{a}}$ & $164.00^{\mathrm{a}}$ & $1216.88^{\mathrm{a}}$ & $11.75^{\mathrm{a}}$ & $0.00^{\mathrm{a}}$ & $628.50^{\mathrm{a}}$ & $9.38^{\mathrm{a}}$ & $702.25^{\mathrm{a}}$ & $25.25^{\mathrm{a}}$ \\
\hline
\end{tabular}


Gemerek bölgesi hasat sonrası kuru pancarları, ICP metodu ile Bor (B), Kalsiyum (Ca), Kadmiyum (Cd), Krom (Cr), Bakır (Cu), Demir (Fe), Magnezyum (Mg), Mangan (Mn), Nikel (Ni), Fosfor (P), Kurşun (Pb), Kükürt (S) ve Çinko (Zn) elementleri bakımından incelendiğinde, Krom (Cr) elementi, bakteri uygulamalarına göre hasat sonrası kuru pancar oranındaki değişimi istatistiksel olarak anlamlı bulunurken (Formülasyon 2: 3,83 - Kontrol: 0,88), diğer elementler istatistiksel olarak anlamlı bulunmamıştır $(\mathrm{p}<0.05)$.

\subsubsection{Yahyalı bölgesi}

Tablo 6. Yahyalı bölgesinde bakteri uygulamaları ile elde edilmiş hasat sonrası kuru pancar numuneleri ICP analiz sonuçları $(\mathrm{p}<0.05)$

\begin{tabular}{|c|c|c|c|c|c|c|c|c|c|c|c|c|c|c|}
\hline Uygulamalar & & $\mathbf{B}$ & $\mathbf{C a}$ & Cd & $\mathbf{C r}$ & $\mathbf{C u}$ & $\mathbf{F e}$ & Mg & Mn & $\mathbf{N i}$ & $\mathbf{P}$ & $\mathbf{P b}$ & $\mathbf{S}$ & $\mathbf{Z n}$ \\
\hline Formülasyon & 1 & $6.75^{\mathrm{a}}$ & $2477.17^{\mathrm{a}}$ & $0.17^{\mathrm{a}}$ & $0.95^{\mathrm{a}}$ & $3.54^{\mathrm{a}}$ & $271.42^{\mathrm{a}}$ & $970.12^{\mathrm{a}}$ & $11.58^{\mathrm{a}}$ & $0.96^{\mathrm{a}}$ & $474.12^{\mathrm{a}}$ & $9.17^{\mathrm{a}}$ & $240.29^{\mathrm{a}}$ & $22.54^{\mathrm{a}}$ \\
\hline Formülasyon & 2 & $6.50^{\mathrm{a}}$ & $7017.5^{\mathrm{a}}$ & $0.00^{\mathrm{a}}$ & $0.92^{\mathrm{a}}$ & $3.12^{\mathrm{a}}$ & $772.87^{\mathrm{a}}$ & $1590.96^{\mathrm{a}}$ & $22.79^{\mathrm{a}}$ & $0.79^{\mathrm{a}}$ & $398.25^{\mathrm{a}}$ & $11.75^{a . b}$ & $256.79^{\mathrm{a}}$ & $23.96^{\mathrm{a}}$ \\
\hline Formülasyon & 3 & $7.17^{\mathrm{a}}$ & $4865.83^{\mathrm{a}}$ & $0.04^{\mathrm{a}}$ & $1.33^{\mathrm{a}}$ & $3.17^{\mathrm{a}}$ & $513.54^{\mathrm{a}}$ & $1276.29^{\mathrm{a}}$ & $18.12^{\mathrm{a}}$ & $0.54^{\mathrm{a}}$ & $449.71^{\mathrm{a}}$ & $13.17^{\mathrm{a} b}$ & $299.71^{\mathrm{a}}$ & $27.71^{\mathrm{a}}$ \\
\hline Kontrol & & $3.87^{\mathrm{a}}$ & $1631.25^{\mathrm{a}}$ & $0.00^{\mathrm{a}}$ & $2.25^{\mathrm{b}}$ & $2.37^{\mathrm{a}}$ & $168.25^{\mathrm{a}}$ & $1219.12^{\mathrm{a}}$ & $9.25^{\mathrm{a}}$ & $0.00^{\mathrm{a}}$ & $429.75^{a}$ & $5.37^{\mathrm{a}}$ & $361.37^{\mathrm{a}}$ & $19.12^{\mathrm{a}}$ \\
\hline
\end{tabular}

Yahyalı bölgesi hasat sonrası kuru pancar ICP metodu ile Bor (B), Kalsiyum (Ca), Kadmiyum (Cd), Krom (Cr), Bakır (Cu), Demir (Fe), Magnezyum (Mg), Mangan (Mn), Nikel (Ni), Fosfor (P), Kurşun (Pb), Kükürt (S), ve Çinko (Zn) elementleri bakımından şeker pancarı incelendiğinde bakteri uygulamalarına göre hasat sonrası kuru pancar oranındaki değişim istatistiksel olarak anlamlı bulunmamıştır $(\mathrm{p}<0.05)$.

Rahimi ve ark. (2016) yaptıkları çalışmada mikro elementlerin şeker pancarı üzerine etkilerine araştırmışlar ve şeker oranı \%15.48-17.77, K varlığı 6.65-7.86 (meq/100 g pulp), Na varlığı 1.30-1.95 (meq/100 g pulp), N varlığı 1.34-7.95 (meq/100 g pulp) arasında değiştiğini ifade etmişlerdir. Çakmakçı ve ark. (2012) yaptıkları çalışmada, azot fikseri ve fosfat çözücü bakterilerin muradiye 10 çay klonunda gelişme, verim ve besin alımı üzerine etkisini araştırmışlar ve PGPR'ın çay gelişmesini teşvik ettiklerini, yaprak makro ve mikro element içeriklerini artırdıklarını tespit etmişler. Karlıdağ ve ark. (2007) elma üzerinde yaptıkları çalışmada, PGPR uygulamasının besin içeriğinde bulunan N, $\mathrm{K}, \mathrm{Zn}, \mathrm{Fe}, \mathrm{Ca}, \mathrm{Mn}, \mathrm{P}$ ve Mg elementlerini Mg hariç arttırdığını ve bitki gelişimi ile verimini olumlu etkilediğini ifade etmişlerdir. 
Şimşek, F., ve ark., Uluslararası Doğu Anadolu Fen Mühendislik ve Tasarım Dergisi / International Journal of Eastern Anatolia Science Engineering and Design (IJEASED)

(2021) 3(1): 350-364

\section{Sonuçlar ve Öneriler}

Sonuç olarak; tarımda şeker pancarı gibi gübre kullanımının fazla olduğu bitkilerin yetiştiriciliğinde, kimyasal gübre kullanımı azaltılarak bakteri içerikli formülasyonlar dahil olmak üzere mikrobiyal gübrelerin hem çevre ve su kaynaklarında kirliliği azaltması hem de temin edilirken yurtdışına bağlı olduğundan maliyetin düşürülmesi gibi birçok konuda faydalı olabileceği için kullanımı artırılmalıdır. Bu çalışmada, literatürdeki çalışmalara paralel olarak, her iki bölgede de verim artışında istatistiksel olarak anlamlı sonuçlar elde edilmiş, digestion oranında Gemerek bölgesinde istatistiksel anlamlılık söz konusu iken Yahyalı bölgesinde artış olmasına rağmen istatistiksel olarak anlamlı bulunmamıştır. Bunun sebebinin bölgesel iklim farklılıkları, toprak yapısı ve çiftçinin kullandığı kimyasal gübre miktarına bağlı olabileceği düşünülmüştür. Buna bağlı olarak kimyasal gübre kullanımı Gemerek bölgede fazla olduğundan bakteri içerikli formülasyonların toprakta dönüştüreceği elementlerin artması ile bitki gelişimini daha olumlu etkilediği düşünülmüştür. Böylece kimyasal gübrelerin tek başına kullanılmamasının hem maliyet hem çevreye/toprağa olumsuz etkilerinin azaltılması yönünden faydalı olacağı, mikrobiyal gübreler ile birlikte kullanılması durumunda bitkiler topraktaki besin elementlerinden daha iyi faydalanarak verim ve kalite parametrelerini olumlu etkileyeceği bu çalışma ile de desteklenmiştir. Çalışma sonucunda kimyasal gübrelerin \%50 azaltılarak bakteri gübreleri ile birlikte kullanımının maliyet ve karlılık açısından daha uygun olacağı düşünülmektedir. 1 nolu bakteri formülasyonun buğday bitkisindeki etkinlik denemeleri Süpersol Biyoteknoloji Anonim Şirketi adına Prof. Dr. Recep Kotan tarafından Erzurum'da yürütülmüştür ve tohum kodlaması yapılan denemede mikrobiyal gübre uygulamasının kontrol uygulamasına göre değerlendirilen bütün parametrelerde artışa sebep olmuştur. Bu artış en düşük \% 2.14 oranı ile hektolitre ağırlığında olurken, en yüksek \% 21.88 ile tane veriminde olmuştur. Bu deneme sonucunda 1 nolu bakteri formülasyonu SS SUPER PAN ticari ismi ile Süpersol Biyoteknoloji Anonim Şirketi adına tescillendirilmiş (Süpersol Biyoteknoloji Lisans no: 1249, SS-Süper Pan Tescil No: 11471), üretim tesisi kurularak piyasaya sürülmüştür.

\section{Yazarların Katkısı}

$\mathrm{Bu}$ çalışma yürütülürken denemenin kurulması, analizlerin yapılması, istatistiksel analizlerin yapılması, makalenin yazılmasında bütün yazarlar eşit oranda katkı sunmuştur. 


\section{Çıkar Çatışması Beyanı}

Yazarlar arasında herhangi bir çıkar çatışması bulunmamaktadır.

\section{Araştırma ve Yayın Etiği Beyanı}

Yapılan çalışmada, araştırma ve yayın etiğine uyulmuştur.

\section{Teșekkür}

Çalışmada kullanılan bakteri formülasyonlarının hazırlanmasında katkıları olan Süpersol Biyoteknoloji Anonim Şirketi’ne teşekkür ederiz.

\section{Kaynaklar}

Artyszak, A., and Gozdowski, D. (2020). The effect of growth activators and Plant Growth-Promoting Rhizobacteria (PGPR) on the soil properties, root yield, and technological quality of sugar beet. Agronomy, 10(9), 1262.

Çakmakçı, R., Dönmez, F., Aydın, A., and Şahin, F. (2006). Growth promotion of plants by plant growthpromoting rhizobacteria under greenhouse and two different field soil conditions. Soil Biology and Biochemistry, 38(6), 1482-1487.

Çakmakçı, R. (2005). Bitki gelişimini teşvik eden rizobakterilerin tarımda kullanımı. Atatürk Üniversitesi Ziraat Fakültesi Dergisi, 36(1), 97-107.

Çakmakçı, R., Ertürk, Y., Dönmez, M. F., Mustafa, E. R. A. T., Kutlu, M., Sekban, R. ve Haznedar, A. (2012). Azot fikseri ve fosfat çözücü bakterilerin Muradiye 10 çay klonunda gelişme, verim ve besin alımı üzerine etkisi. International Journal of Agricultural and Natural Sciences, 5(2), 176-181.

Chen, Y., Mei, R., Lu, S., Liu, L. and Kloepper, J. W.(1996). The use of yield increasing bacteria (YIB) as plant growth-promoting rhizobacteria in Chinese agriculture. Utkhede, RS \& Gupta, VK (Ed.) Management of soil born diseases. Ludhiana. Kalyani Publishers, 165-184.

Çınar, V. M. (2018). Farklı bitki büyüme teşvik edici bakteri uygulamalarının şeker pancarında (Beta vulgaris var. saccharifea L.) verim ve şeker içeriğine etkisi (Master's thesis). Adnan Menderes Üniversitesi Fen Bilimleri Enstitüsü, Aydın.

Ekinci, M., Turan, M., Yildirim, E., Güneş, A., Kotan, R. and Dursun, A.(2014). Effect of plant growth promoting rhizobacteria on growth, nutrient, organic acid, amino acid and hormone content of cauliflower (Brassica oleracea 1. var. botrytis) transplants. Acta Sci. Pol. Hortorum Cultus, 13 (6): 71 85.

Erman, M., Kotan, R., Çakmakçı, R., Çı̆̆, F., Karagöz, F. ve Sezen, M. (2010, Haziran). Van Gölü Havzası'ndan izole edilen azot fikseri ve fosfat çözücü bakterilerin buğday ve şeker pancarında büyüme ve verim özellikleri üzerine etkileri. Türkiye IV. Organik Tarım Sempozyumu (s. 325-329). Erzurum.

Gökçe, A. Y. ve Kotan, R. (2014, Şubat). Buğday kök çürüklüğ̈̈ne neden olan Bipolaris sorokiniana (Sacc.) fungusunun PGPR ve antogonist bakteriler kullanllarak kontrollü koşullarda biyolojik mücadele imkânlarının araştırılması. Türkiye V. Bitki Koruma Kongresi (s. 358). Antalya. 
Şimşek, F., ve ark., Uluslararası Doğu Anadolu Fen Mühendislik ve Tasarım Dergisi / International Journal of Eastern Anatolia Science Engineering and Design (IJEASED)

(2021) 3(1): 350-364

Gökçe, A. Y., ve Kotan, R. (2016). Buğday kök çürüklüğüne neden olan Bipolaris sorokiniana (Sacc.)'ya karş1 PGPR ve biyoajan bakterileri kullanılarak kontrollü koşullarda biyolojik mücadele imkanlarının araştırılması. Bitki Koruma Bülteni, 56(1), 49-75.

Kaplan, M., Aktaş, M., Güneş, A., Alpaslan, M., ve Sönmez, S. (2000). Türkiye Gübre Üretim ve Tüketiminin Değerlendirilmesi. V. Türkiye Ziraat Mühendisliği Teknik Kongresi, 881-900.

Karagöz, F. P. and Dursun A. (2019). Effects of Different PGPR Formulations, Chemical Fertilizers and Their Combinations on Some Plant Growth Characteristics of Poinsettia. Yüzüncü Yıl Üniversitesi Tarım Bilimleri Dergisi, 29, 9-15.

Karlidag, H., Esitken, A., Turan, M. and Sahin, F. (2007). Effects of root inoculation of plant growth promoting rhizobacteria (PGPR) on yield, growth and nutrient element contents of leaves of apple. Scientia Horticulturae, 114(1), 16-20.

Khan, N., \& Bano, A. (2019). Growth and yield of field crops grown under drought stress condition is influenced by the application of PGPR. In Field Crops: Sustainable Management by PGPR (pp. 337349). Springer, Cham.

Kotan, R. (2002). Doğu Anadolu Bölgesi'nde yetiştirilen yumuşak çekirdekli meyve ağaçlarından izole edilen patojen ve saprofitik bakteriyel organizmaların klasik ve moleküler metotlar ile tanısı ve biyolojik mücadele imkânlarının araştırılması. Doktora Tezi, Atatürk Üniversitesi, Fen Bilimleri Enstitüsü, Bitki Koruma Anabilim Dalı, Erzurum. S: 217.

Meena, P. and Rai, A. K. (2017). Effect of PGPR on morphological properties of different varieties of wheat (Triticum aestivum). The Pharma Innovation, 6 (7, Part D), 271.

Mertens, D. (2005a). Plants preparation of laboratory sample. In: Horwitzand W, Latimer GW, editors. Official Methods of Analysis of AOAC International. 18th ed. Gaithersburg, MA, USA: AOAC International, pp. 1-2.

Mertens, D. (2005b). Metal in plants and pet foods., In: Horwitz W, Latimer GW, editors. Official Methods of Analysis of AOAC International. 18th ed. Gaithersburg, MA, USA: AOAC International, pp. 3-4.

Rahimi, A., Arslan, N., ve Esmzad, S. (2016). Mikro Elementlerin (Fe, Zn, B ve Mn), Şekerpancarında (Beta vulgaris L.) Kalite Kriterleri Üzerine Etkisi. Tarla Bitkileri Merkez Araştırma Enstitüsü Dergisi, 25(Ö̈el Sayl-2), 71-76.

Seema, K., Mehta, K., \& Singh, N. (2018). Studies on the effect of plant growth promoting rhizobacteria (PGPR) on growth, physiological parameters, yield and fruit quality of strawberry cv. chandler. J Pharmacog Phytochem, 2(7).

Szekeres, A. (2005). Echophysiological and molecular investigation of Trichoderma strains isolated from winter wheat rhizosphere. Acta Biologica Szegediensis, 49(3-4), 61-61.

Taški-Ajduković, K., Nagl, N., Ćurčić, Ž. and Zorić, M. (2017). Estimation of genetic diversity and relationship in sugar beet pollinators based on SSR markers. Electronic Journal of Biotechnology, 27, $1-7$.

Tuğcu, G. (2009). Pankobirliğin 4634 Sayılı Şeker Kanunu çerçevesinde ülke şeker piyasasındaki yerinin şeker pancarı üreticisi açısından değerlendirilmesi (Master's thesis). Namık Kemal Üniversitesi, Tekirdağ.

URL-1: http://www.turkseker.gov.tr/data/dokumanlar/2019_Sektor_Raporu.pdf, (Erişim Tarihi: 25.12.2020). 
URL-2: https://www.kayseriseker.com.tr/Site/YiBelge/a58cec44-7254-46f2-b181-fa4fab144deb.pd f, (Erişim Tarihi: 06.05.2021).

URL-3:https://www.foodonline.com/doc/betalyser-0001, (Erişim Tarihi: 22.12.2020).

URL-4:https://www.mevzuat.gov.tr/mevzuat?MevzuatNo=5215\&MevzuatTur=7\&MevzuatTertip= (Erişim Tarihi: 05.05.2021).

Yagmur, B., and Gunes, A. (2021). Evaluation of the Effects of Plant Growth Promoting Rhizobacteria (PGPR) on Yield and Quality Parameters of Tomato Plants in Organic Agriculture by Principal Component Analysis (PCA). Gesunde Pflanzen, 1-10.

Yasmin, F., Othman, R., Vijayan, H., \& MHM, N. (2021). Response of Sweet Potato to Application of Pgpr and N Fertilizer. Annals of the Romanian Society for Cell Biology, 10799-10812. 